\title{
Resource Management in Crisis Situations
}

\author{
Mete Gündoğan ${ }^{1}$, Murat Ata ${ }^{2 *}$ \\ ${ }^{1}$ Ankara Yıldırım Beyazıt University, Department of Industrial Engineering, Ankara, Turkey, (ORCID: 0000-0002-6753-9954), metegundogan@ybu.edu.tr \\ ${ }^{2 *}$ Ankara Y1ldırım Beyazıt University, Graduate School of Natural Sciences, Ankara, Turkey, (ORCID: 0000-0002-3770-9983), murata@hotmail.com
}

(First received 22 June 2021 and in final form 23 November 2021)

(DOI: $10.31590 /$ ejosat.955560)

ATIF/REFERENCE: Gündoğan, M., Ata, M. (2021). Resource Management in Crisis Situations. European Journal of Science and Technology, (27), 935-941.

\begin{abstract}
In crisis situations, one of the most important issue will be the supply of products and raw materials. In addition to supply, it is necessary to be prepared, especially in cases where basic necessities are not sufficient for the entire society. With our existing technological capabilities, almost every citizen can be tracked separately, often instantly where and what he is doing can be observed. We will try to put aside the ethical discussions of this part of the subject and focus on how we can benefit from these opportunities. Of course, the most ideal thing is that every citizen, regardless of his/her financial power, position in society, job or title, consumes as much resources as his true need with his consent without any compulsion. But in the case of coercive situations, it may be necessary to ensure that the division is conducted fairly and transparently by the authority. In this study, we will try to put a model proposal for resource management system with using one of the systems engineering methods, "Structured System Analysis and Design Method" and relational database design. Of course the model will be not so detailed, but will be functional for at least vital needs.
\end{abstract}

Keywords: Database, Pandemic, Resource Management, Systems Engineering

\section{Kriz Durumlarında Kaynak Yönetimi}

$\ddot{O} z$

Kriz durumlarında, en önemli konulardan biri ürün ve hammadde temini olacaktır. Arzın yanı sıra, özellikle temel ihtiyaçların tüm toplum için yeterli olmadığı durumlara hazırlıklı olmak gerekir. Mevcut teknolojik yeteneklerimizle, hemen hemen her vatandaş ayrı ayrı izlenebilir, çoğu zaman nerede ve ne yaptığını anında gözlemlenebilir durumdadır. Konunun bu bölümünün etik tartışmalarını bir kenara bırakmaya çalışacağız ve bu firsatlardan nasıl yararlanabileceğimize odaklanacağız. Tabii ki en ideal olan, her vatandaşın, finansal gücü, toplumdaki konumu, işi veya unvanı ne olursa olsun, herhangi bir zorlama olmadan rızasıyla gerçek ihtiyacı kadar kaynak tüketmesidir. Ancak zorlayıcı durumlar söz konusu olduğunda, bölüşmenin otorite tarafından adil ve şeffaf bir şekilde yürütülmesini sağlamak gerekli olabilir. Bu çalışmada, sistem mühendisliği yöntemlerinden biri olan "Yapılandırılmış sistem analizi ve tasarım yöntemi” ve "ilişkisel veri tabanı tasarımı” kullanılarak kaynak yönetim sistemi için bir model önerisi sunmaya çalışacağız. Tabii ki model çok ayrıntılı olmayacak ancak en azından hayati ihtiyaçlar için işlevsel olacaktır.

Anahtar Kelimeler: Veri tabanı, Pandemi, Kaynak Yönetimi, Sistem Mühendisliği

\footnotetext{
*Corresponding Author: murata@hotmail.com
} 


\section{Introduction}

As it is known, the whole world is going through a troubled pandemic. It is also clear how unprepared almost all states and institutions are for the epidemic. Many of the work previously done on paper did not work, and the predictions turned out to be wrong. It is obvious that there are dramatic differences between the conditions of epidemics encountered in history and today and we need new systematic approaches that first and fore top the realities of life and human behavior. In May 2021, COVID-19 has caused in more than 170 million cases and over 3.400.000 deaths globally, over 5.200.000 cases and about 47.000 deaths in Turkey ("Worldometers," n.d.). The first case of Turkey was announced by the Ministry of Health on March 11, 2020.

The COVID-19 pandemic has brought numerous challenges and problems to the food industry and supply chain. People have increased consumption and stocking up of such goods due to the isolation and quarantine orders by various governments. Food business have had to deal with this demand despite business operations and labor capacity constraints (COVID-19 Guidance: Businesses and Employers | CDC 2020; Montenegro and Young 2020). With the available literature, operational challenges are found in five key areas: food safety, production, logistics, pricing and food systems survivability (Montenegro \& Young, 2020). We can add an additional item to this list: Distribution to the public. Maybe not for just for pandemic but any other crisis situations and maybe not just foods but any other vital goods or services should have their own special distribution plans too.

$27 \%$ of the world's population have access within a radius of fewer than 100 kilometers. When disrupted by logistics constraints and outflow channels, difficulty in both supply and local availability would arise. Thus, during a pandemic, food supply chains have the tendency to become more vulnerable to disruptions caused by such crisis (Impact Of Global Food Supply Chains During A Global Pandemic - AGRITECTURE n.d.; Montenegro and Young 2020). The COVID-19 pandemic has aggravated food insecurity in urban centers because of the disruption in the food supply chain, aggravation of the physical and economic barriers that restrict access to food, and the catastrophic increase in food waste because of labor shortages (Lal, n.d.).

Localization like small garden producing could be very important to access foods. Many sites have large areas of lawn that can actually be used for planting and growing crops, which would actually consume much less water. The authorities can support local food producing with free education or seed supply.

\section{The Pandemic}

Epidemic can be described as a disease in a community or region, and pandemic can be described as a widespread occurrence of disease in many countries or continents (ÜSTÜN-, 2020).
Table 1. A historical data of some of past pandemic diseases (LePan, 2020):

\begin{tabular}{|c|c|c|c|}
\hline Name & $\begin{array}{l}\text { Time } \\
\text { period }\end{array}$ & $\begin{array}{l}\text { Type / Pre-human } \\
\text { host }\end{array}$ & Death toll \\
\hline Antonine Plague & $165-180$ & $\begin{array}{l}\text { Believed to be either } \\
\text { smallpox or measles }\end{array}$ & $5 \mathrm{M}$ \\
\hline $\begin{array}{l}\text { Japanese } \\
\text { smallpox } \\
\text { epidemic }\end{array}$ & $735-737$ & Variola major virus & $1 \mathrm{M}$ \\
\hline $\begin{array}{l}\text { Plague of } \\
\text { Justinian }\end{array}$ & $541-542$ & $\begin{array}{l}\text { Yersinia pestis bacteria } \\
\text { / Rats, fleas }\end{array}$ & $30-50 \mathrm{M}$ \\
\hline Black Death & $1347-1351$ & $\begin{array}{l}\text { Yersinia pestis bacteria } \\
\text { / Rats, fleas }\end{array}$ & $200 \mathrm{M}$ \\
\hline $\begin{array}{l}\text { New World } \\
\text { Smallpox } \\
\text { Outbreak }\end{array}$ & $\begin{array}{l}1520- \\
\text { onwards }\end{array}$ & Variola major virus & $56 \mathrm{M}$ \\
\hline $\begin{array}{l}\text { Great Plague of } \\
\text { London }\end{array}$ & 1665 & $\begin{array}{l}\text { Yersinia pestis bacteria } \\
\text { / Rats, fleas }\end{array}$ & 100,000 \\
\hline Italian plague & $1629-1631$ & $\begin{array}{l}\text { Yersinia pestis bacteria } \\
\text { / Rats, fleas }\end{array}$ & $1 \mathrm{M}$ \\
\hline $\begin{array}{l}\text { Cholera } \\
\text { Pandemics 1-6 }\end{array}$ & $1817-1923$ & V. cholerae bacteria & $1 \mathrm{M}+$ \\
\hline Third Plague & 1885 & $\begin{array}{l}\text { Yersinia pestis bacteria } \\
\text { / Rats, fleas }\end{array}$ & $\begin{array}{l}\text { 12M (China } \\
\text { and India) }\end{array}$ \\
\hline Yellow Fever & $\begin{array}{l}\text { Late } \\
1800 \mathrm{~s}\end{array}$ & Virus / Mosquitoes & $\begin{array}{l}100,000- \\
150,000 \\
\text { (U.S.) }\end{array}$ \\
\hline Russian Flu & $1889-1890$ & $\begin{array}{l}\text { Believed to be } \mathrm{H} 2 \mathrm{~N} 2 \\
\text { (avian origin) }\end{array}$ & $1 \mathrm{M}$ \\
\hline Spanish Flu & 1918-1919 & H1N1 virus / Pigs & $40-50 \mathrm{M}$ \\
\hline Asian Flu & $1957-1958$ & $\mathrm{H} 2 \mathrm{~N} 2$ virus & $1.1 \mathrm{M}$ \\
\hline Hong Kong Flu & $1968-1970$ & $\mathrm{H} 3 \mathrm{~N} 2$ virus & $1 \mathrm{M}$ \\
\hline HIV/AIDS & $\begin{array}{l}\text { 1981- } \\
\text { present }\end{array}$ & Virus / Chimpanzees & $25-35 \mathrm{M}$ \\
\hline Swine Flu & 2009-2010 & H1N1 virus / Pigs & 200,000 \\
\hline SARS & $2002-2003$ & $\begin{array}{l}\text { Coronavirus / Bats, } \\
\text { Civets }\end{array}$ & 770 \\
\hline Ebola & 2014-2016 & $\begin{array}{l}\text { Ebolavirus / Wild } \\
\text { animals }\end{array}$ & 11,000 \\
\hline
\end{tabular}




\begin{tabular}{|llll}
\hline Name & $\begin{array}{l}\text { Time } \\
\text { period }\end{array}$ & $\begin{array}{l}\text { Type / Pre-human } \\
\text { host }\end{array}$ & Death toll \\
\hline MERS & $\begin{array}{l}2015- \\
\text { Present }\end{array}$ & $\begin{array}{l}\text { Coronavirus / Bats, } \\
\text { camels }\end{array}$ & 850 \\
\hline COVID-19 & $\begin{array}{l}\text { 2019- } \\
\text { Present }\end{array}$ & $\begin{array}{l}\text { Coronavirus - } \\
\text { Unknown (possibly } \\
\text { pangolins) }\end{array}$ & $2.4 \mathrm{M}$ \\
\hline
\end{tabular}

Of course it is very important to take lessons from past experiences. But when we compare our environment and abilities with other pandemic periods in history, we can see many differences. Perhaps the most important of these are the development of communication technologies, as well as individualization in society and the dramatic changes in social structures. When we evaluate in terms of the affected mass, even if the closest example is seen as HIV -which has entered our lives since the 80 's- when we look at the risk and ease of transmission, old influenza outbreaks can be taken as an example. However regardless of the similarities, it is not possible to say that COVID 19 is close to previous pandemics in terms of both geographical spread and disease character. When sociological and technological differences are added to this, it is obvious that we are faced with a brand new disease and problems that we have not encountered before. It is clear that we have to look for solutions to these problems that have not been applied before. Many practices and measures taken have been tried to be regulated through trial and error and by observing their effects on both individuals and society.

There is a report prepared by General Directorate of Public Health with the title The Pandemic Influenza National Preparedness Plan in 2019 (TC Halk Sağlığı Genel Müdürlüğü, 2019). In that report, it is assumed that the pandemic period will be 10-12 weeks if no intervention is made. The report also includes some -not so accurate- scenarios regarding the severity of the pandemic. But now, we all know the fact which is different.

Compared with past pandemics, the biggest difference of our period is undoubtedly the speed and ease of accessing data. In addition to ensuring the rapid dissemination of information, evolving communication capabilities have made it easier to manipulate people. It is not clear which information is true and which is false, and the reliability of the sources has been questioned. Even the structures established for this purpose are discussed and suspicions arise that they are working in the interests of the financiers and groups to which they belong. It is also a big problem that people can access all kinds of data so quickly, regardless of whether it is right or wrong, and that it contributes to its dissemination and development by evaluating it completely subjective in line with their own ideas and feelings. There is a laziness to turn data into qualified information. Evaluations are generally in line with the directions of the individuals and groups who are followed or valued.
This is a great opportunity for foci who have the necessary and adequate instruments. It has been opened the way for them to reach the goals that would take a very long time or even impossible to reach under normal conditions, in a relatively short time. The most obvious example of this, which no one denies, is the change in the current globalization design and the transition to a New Order. "Although this will require a historic leap, major crises often open the political space for radical reforms. Precisely at a time when rules-based multilateralism is in retreat, perhaps the fear and losses arising from COVID-19 will encourage efforts to bring about a better model of globalization." (Derviş \& Strauss, 2020)

\section{The Problem}

During this period, many private sectors experienced difficulties. We're in a consumption-based society, and in the early periods when people were locked up in their homes, they couldn't make the purchases they were used to. As a result, sales declined. Physical contact almost disappeared, and because of this there was a significant increase in internet sales. Inevitably, there were disruptions to cargo services. In addition, there have been some disruptions to supply chains and deliveries.

Employees have made serious sacrifices to ensure that some critical services can continue without disruption. Many government and municipal institutions have had to close certain departments or limit most of their services. Life has come to a standstill, except for the fulfillment of essential needs.

The measures that needed to be taken were either not taken or were late. As a result, constant changes were made in decisions and practices. From time to time, practices that had no use in fighting the epidemic came into force. The consequences of the practices in society and their effects in the short or medium term were not well calculated. This led to either a got step back or at least a waste of very valuable time.

There have been serious problems, especially in the health sector. Both mask and disinfectant production and physical environments in hospitals were insufficient to meet the needs. Let's look at the example of surgical mask supply.

Actually, mask is very basic and easy to produce stuff. Finding a mask was a problem in itself. Initially, overpriced mask sales were made by manufacturers who wanted to take advantage of the opportunity. People were desperate to pay up to $10 €$ for $30 \mathrm{kr}$ masks. Then, sales of the mask were banned and told they could only be obtained from pharmacies. After that, it was announced that only the codes sent to the phones would be sold. A lot of people didn't have a code on their phones. Meanwhile, with tons of medical supplies were provided to many countries, especially those in Europe. Although this behavior is humanitarian, it has caused criticism of the government for primarily helping others rather than meeting the needs of their own people. Some "entrepreneurs" began to produce under dubious conditions in 
order to take advantage of the opportunity. In short, approximately for first 3 or 4 months finding mask was very big problem.

It has caused a long debate, as it has not been clear whether the use of a mask is necessary, who should use it even if necessary, by both local authorities and the World Health Organization. At the time of the preparation of this document, the situation was still not clear and satisfactory.

Also trading a/was a big problem. Small tradesmen and SMEs in particular have had a very difficult time and have not been able to get enough support from the state. The government had given limited support them. Low-interest loans and deferred debits were good, but not enough. Because "debit was still debit" and "interest was still interest". Many of other countries have given their small companies unrequited and unconditional monetary support.

Locking up people and the created atmosphere of fear have caused many social and individual problems. Maybe most of us have expected some changes but only started to realize what was happening in fact after 1 year. In many areas, such as health and trade, as well as education, friendships, eating habits, worship requirements, tourism, behavior of the private and public service sectors, it was necessary to go beyond the usual standards. As the academic researches and many projects carried out were concluded, both sociological and psychological consequences began to emerge about what happened. Since these studies can be done for a limited target audience and certain regions, they are at a level that can only give us an idea about the whole. Undoubtedly, more detailed and comprehensive studies will be conducted over time and due diligence will be made more accurately.

In previous pandemics, although it was seen that it was necessary to provide clear and clear information to the public in order to reduce fear and panic and build trust8, this sensitivity was not shown. From the early days of the pandemic, "if you don't...!" messages of fear continue to be given.

If we have summarized the problem, we could say "we were unprepared". What about now?

\section{Analyzing the problem}

\subsection{What is system?}

Naturally, when you say "System" everyone has a different meaning in their mind. The nature of this meaning is, without doubt, closely related to the education we receive, the work we do, the environment we live in, the events we deal with, in short, with our acquis. The system can be an operating system or network structure for a person interested in computers, a whole set of parts that make up a machine or factory for engineers, and a training process or a supply chain for soldiers. However, even though it is quite big and complicated, such as "health system, education system, economic system" we all hear, there are also organizations where almost everybody unites in a common denominator.

The system can generally be summarized as a whole that interacts with its environment, parts of that whole, and all the relationships e-ISSN: 2148-2683 between them. According to Aristotle, "The whole is more than the sum of its parts. The part is more than the fraction of the whole". So when it comes to systems, two plus two can be more than four. In the same way, when four of them are split in two, the pieces can be larger than two.

Systems are organized and complex structures. The first structure that needs to be revived in our minds is human. When we went to the starting point, Allah (CC) first "wished" to create man. So at the first stage, man was just an idea. He then gave it the most beautiful shape and shaped it with soil. He then breathed out of his soul and completed the creation. Then man came into the world and had to prepare for world conditions for a while. He learned to survive and take advantage of the world's blessings. Eventually, he got old, died, and returned to the soil. Here we can see that there is a cycle that repeats for each person and has certain stages. If we need to sort the stages of this cycle (Hitchins, 2015b);

- Conception

- Design

- Creation

- Transition to Use

- Use, Life

- Senility, aging

- Replacement

We actually have a similar cycle in the world we live in. Doesn't it all start with an idea and end with death?

Not only these stages, but also inside the body, we see that there is a perfect mechanical system and it is in balance. It consists of cells, tissues, organs, organ systems and the organism i.e. the body, respectively. When people come together they form families or communities, then they form tribes or nations. It can be easily identified that each of these is a subsystem of the other. So we can talk about a hierarchical structure between systems (Hitchins, 2015a).

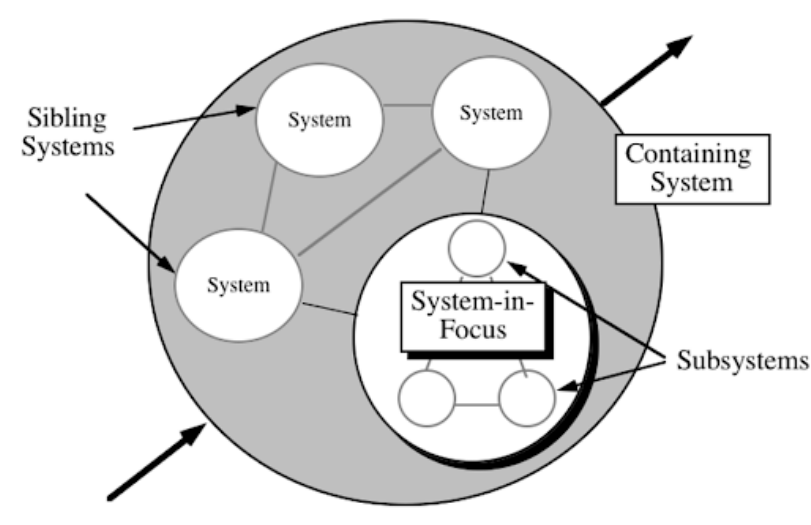

Figure 1

It is obvious that even if we understand what the system is, it will not be enough. So how do we design a system? What should we pay attention to? When is the "thing" we are trying to do become a functional system? Do mechanical engineers or accountants suffice to design a system like the transportation system? Or is a new actor needed to bring all the disciplines together? Are there any 
parameters other than what we can see and hold with our eyes?

\subsection{Systems Engineering}

Well, would be engineering of the system? What do we actually mean telling by "systems engineering"? Although there are many different definitions according to those who think and care about the subject, there are basically agreed upon certain features. Let's sort these properties before making a definition with a single sentence (Hitchins, 2007):

- Wholes

- Synthesis of the whole from complementary parts.

- Finding answers/solutions to 'whole problems

- Analysis

- Design

- Complexity

- Discipline and science

- Integrity

- Planning

The catch-all definition of systems engineering is;

Systems engineering is the art and science of creating whole solutions to complex problems (Hitchins, 2007).

or

Systems engineering is synthesizing a complex system from less complex systems.

The key point here is to isolate the jobs and make them independent departments of each other. In other words, "decomposition and abstraction".

When you design a system to solve any complex problem, as you apply what needs to be and correct its errors, you get closer to the perfect, and then the more you start to look like the truly perfect one. The issue here is the "organization" knowledge and ability rather than the technology or possibilities you use.

In fact, system design is a natural part of our lives. When we cook, we act in a certain order. The cleaning works, the layout of the house and the supply of the work can always be considered as small systems within themselves. When we look around, we can see many designed / synthesized systems, some of them are interactive, some are hierarchical and some are independent.

SE deals with solving problems. When searching for optimal solutions various methods are used. The best known of these is the Systems Engineering Problem-solving Paradigm or SEPP (figure 2). It is found open or hidden in most transactions. SEPP is a solution-oriented method (Hitchins, 2015a).

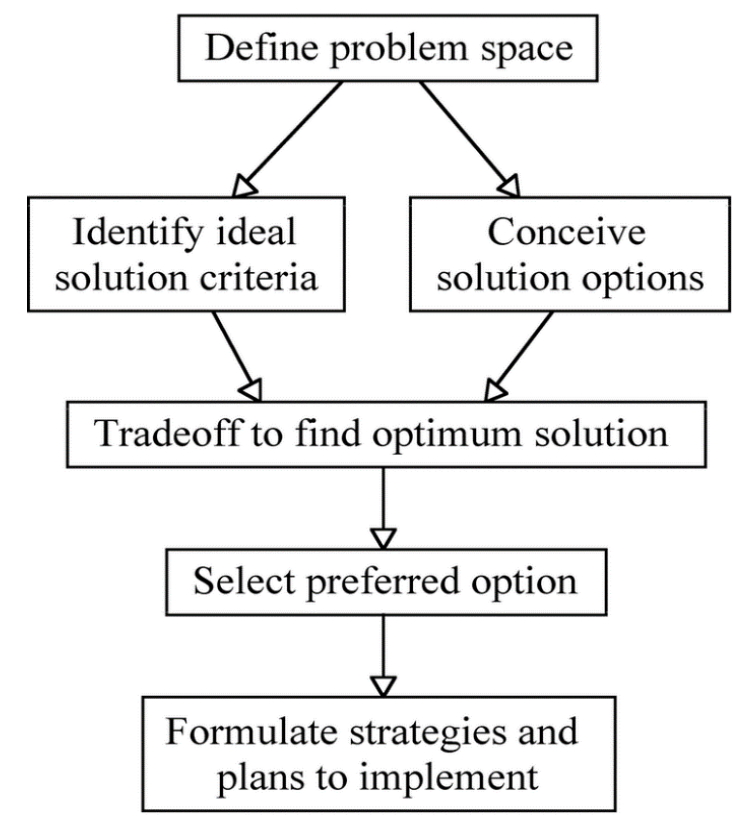

Figure 2

\section{Building a Proposal}

\subsection{Systems Engineering Approach}

Planning is critical to mitigating the sudden and potentially catastrophic impact of an infectious disease pandemic on society. National pandemic policy documents cover a wide variety of control options, often with nonspecific recommendations for action (Shearer, Moss, McVernon, Ross, \& McCaw, 2020). Pandemic preparedness in Turkey began in 2004 and entered into legislation with the Prime Minister's circular in 2006 ("Wikipedia Web Page," 2020). As mention before, National Pandemic Influenza Preparedness Plan was published by the Ministry of Health in December 2019. It has very detailed instructions but includes mostly preparation rules about health field and arrangements of human resources. There is almost nothing inside it about economy or production.

For crisis situations, we need a useful plans that also have some alternative applications. Epidemic prediction algorithms, mathematical modeling and simulations can be used to guide decision makers. But due to mutations and variants of the virus, accurate prediction may not always be made. However, even if it cannot meet all possible scenarios, there is a need to meet the basic needs of both society and individuals and to plan to maintain vital functions.

First we try to design a system and use the data we have. After designing phase, a simulation can be useful to understand what can be happened in which circumstances. Eventually, it comes to speed and reliability. But we do not have unlimited resources and we have to use them effective and wisely.

There are some methods (or tools) for designing systems. We are going to use "Structured System Analysis and Design Method" (SSADM). The whole structure and sub-levels is not subject of this study. We just show the very top level of the proposed system for a province. We will also use database tables and relationship diagrams to show overall structure. Our aim will be to present key points as clearly and comprehensively as possible, to establish a model that going to be easily adapted to various situations about product supply 
chains.

Here is the first and top level of the work:

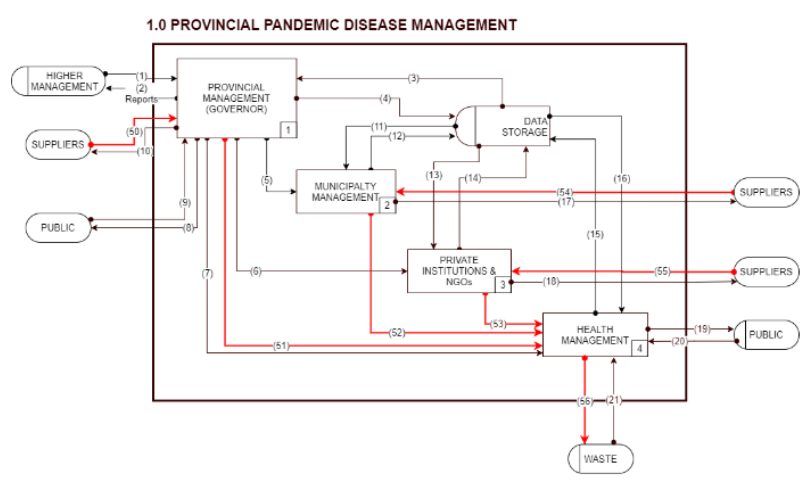

Figure 3. Black lines for information, red lines for material flow.

There are 4 independent departments and 1 data store:

1. Provincial Management (Governor). This department is headed by The Deputy Governor who is accountable to the Governor. Because, the Governor has to manage all province and has other responsibilities. In the board, the Departments, the Mayoralty, law enforcement, scientists, provincial directorates of ministries, food sector, some SMEs and some key suppliers are represented. This department manage the crisis. It gets the general policy from and reports the situation to the Higher Management.

2. Municipality Management. It should ready to serve to the public more than ever. Because, the city has a significant amount of supplies and manpower. It must have made them available to the Health Management.

3. Private Institutions and NGOs. Companies and organizations also get advices and orders from the Governorship and supports the Health Management.

4. Health Management. We can say, everyone work for this department.

5. Data Storage. Central software and database warehouse. Every department *must* connect this store and share information.

Inputs:

(1) General Policy

(9) Public Information

(21)Waste Information

$(50,54,55)$ Supply Materials

follow-up

(20) Determine infected people (56) Special waste

\section{Departmental Relations:}

$(51,52,53)$ Medical and vital supplies and medicine

The rest is information sharing via the Data Store.

As can be seen from our SSADM chart, one of the most important parts will be the supply of products and raw materials. In addition to supply, it is necessary to be prepared, especially in cases where basic necessities are not sufficient for the entire society.

With our existing technological capabilities, almost every citizen can be tracked separately, often instantly where and what he is doing can be observed. We will try to put aside the ethical discussions of this part of the subject and focus on how we can benefit from these opportunities. Of course, the most ideal is that every citizen, regardless of his financial power, position in society, job or title, consumes as much resources as his true need with his consent without any compulsion. But in the case of coercive situations, it may be necessary to ensure that the division is conducted fairly and transparently by the authority.

\subsection{Database}

We have designed a relational database model, which stores data about material and goods supply chain. First, let we make some quick explanations about the database.

MySQL, the most popular Open Source SQL database management system, is developed, distributed, and supported by a private corporation ("MySQL," n.d.). We used MySQL to design the database and the chart prepared with MySQL Workbench application.

Each box in the chart shows the database tables. The rows in the tables refer to the information stored, that is, the columns. Dashed lines between them were used to show the relationship between tables. In this design, it was enough to use only one-to-many type relationships. This means that there can be an infinite number of records in the associated table, for a single record in the source table. For example, a father may have more than one child, but each child can have only one father. Another example is that an invoice has only one header record, but can have an infinite number of details. Another thing about relationships is data consistency. By establishing a relationship between tables, for example, a detail record of an invoice without a header record cannot be entered. Even if it cannot be controlled by the software, the database engine does not allow such inconsistencies. Similarly, record deletions that can cause inconsistency are prevented.

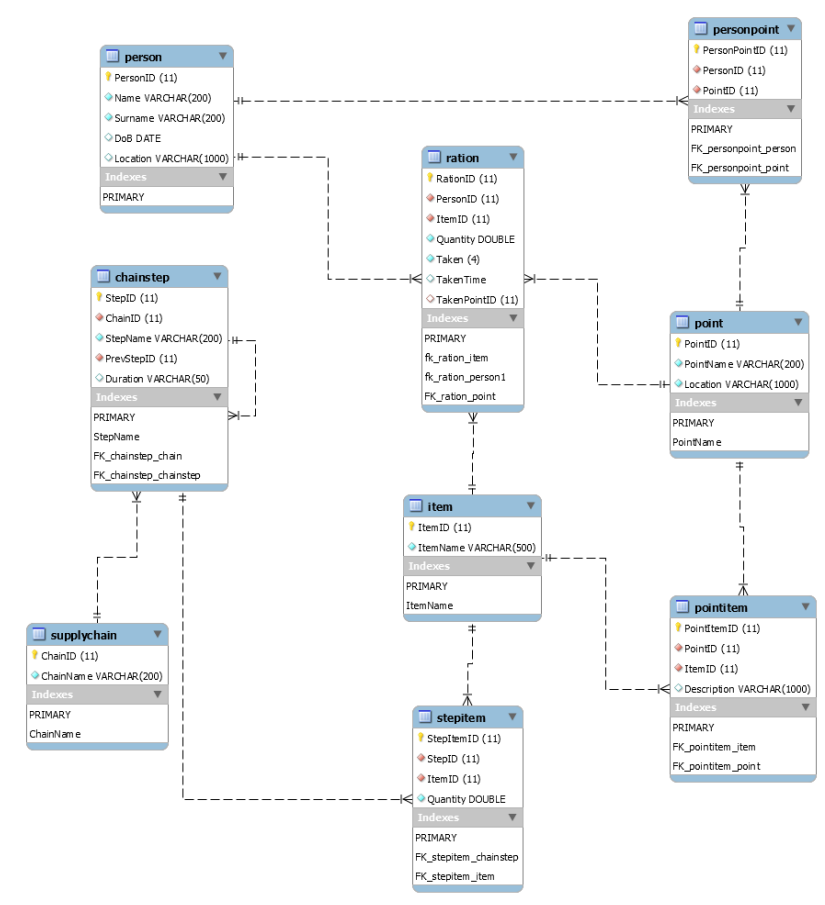

Figure 4

Fields with yellow key are primary keys (or indexes). Records in these fields can be unique within the entire table. This means that there cannot be two records with the same value for this field. 
Indexes section shows index fields of the table. These fields are used to search data faster and access certain records, even if they do not have unique values.

\subsection{The Design}

There are 3 main (core) objects in the database: Person, item and point. The other tables have been used to describe the relationships between these objects. "The ration" is at the center of the diagram, but it depends on the main objects. Without them, we can't define any rights. Ration is a fixed amount of a commodity officially allowed to each person during a time of shortage, as in wartime or a crisis situations.

With our database design, the supply chain of each product can be defined step by step. It can be defined how long these steps take, how many quantities the product or sub-products can be produced or used at a time. Not only at what points the products can be found, but also the amount of rations of each person, from which points they can obtain these rights, can be stored until the date and time they receive delivery.

In addition, if local farmers identify their products to the system and leave them at delivery points, it will be possible for people in need to have information about this situation and access vital nutrients without the need for any intermediaries. With some small improvements, many details and vital information can be integrated into the system. For example, by exchanging data with the citizenship and address system, the population and address of each family can be provided. After local manufacturers define their net capacity in the system, supply and demand in a specific geographical area will be determined. If we go one step further, there may be problems with citizens' access to an extremely vital substance such as water due to failures in the water distribution system. In this case, again, with this database design, fair distribution of local water resources, such as special built water lines or drilled wells, can be made.

\section{Conclusions}

We have used information technologies' database design and systems engineering approach to build a solution proposal for access product and services in crisis situations. Of course, the most ideal thing is that every citizen, regardless of his/her financial power, position in society, job or title, consumes as much resources as his true need with his consent without any compulsion. With our solution, we can follow the supply chain of each product, the steps of these chains and each raw material of the products in detail. In the other hand, we can track every citizens' needing and make them access to the enough food or services. And our proposed system made all of these transparent.

\section{References}

COVID-19 Guidance: Businesses and Employers | CDC. (2020). Retrieved June 13, 2021, from https://www.cdc.gov/coronavirus/2019ncov/community/guidance-business-response.html

Derviş, K., \& Strauss, S. (2020). What COVID-19 means for international cooperation. Retrieved December 25, 2020, from The Brookings Institution website: https://www.brookings.edu/opinions/what-covid-19- means-for-international-cooperation/

Hitchins, D. K. (2007). Systems Engineering: A 21st Century Systems Methodology. Wiley.

Hitchins, D. K. (2015a). System Models Website. Retrieved March 1, 2021, from http://systems.hitchins.net/systems/systemsmodels/index.html

Hitchins, D. K. (2015b). Youtube Video. Retrieved February 20, 2021, from https://youtu.be/BEvW9B64tsM?t=292

Impact Of Global Food Supply Chains During A Global Pandemic - AGRITECTURE. (n.d.). Retrieved June 13, 2021, from https:/www.agritecture.com/blog/2020/5/7/impact-ofglobal-food-supply-chains-during-a-global-pandemic

Lal, R. (n.d.). Home gardening and urban agriculture for advancing food and nutritional security in response to the COVID-19 pandemic. https://doi.org/10.1007/s12571-02001058-3/Published

LePan, N. (2020). Visualcapitalist. Retrieved February 20, 2021, from https://www.visualcapitalist.com/history-ofpandemics-deadliest/

Montenegro, L. D., \& Young, M. N. (2020). Operational Challenges in the Food Industry and Supply Chain during the COVID-19 Pandemic: A Literature Review. 2020 7th International Conference on Frontiers of Industrial Engineering (ICFIE), 1-5. https://doi.org/10.1109/ICFIE50845.2020.9266743

MySQL. (n.d.). Retrieved May 30, 2021, from https://dev.mysql.com/doc/refman/8.0/en/what-ismysql.html

Shearer, F. M., Moss, R., McVernon, J., Ross, J. V, \& McCaw, J. M. (2020). Infectious disease pandemic planning and response: Incorporating decision analysis. PLoS Medicine, 17(1), $1 . \quad$ Retrieved from https://doi.org/10.1371/journal.pmed.1003018

TC Halk Sağlığı Genel Müdürlüğü. (2019). Pandemik Influenza Ulusal Hazırlık Planı.

ÜSTÜN-, Ç. (2020). Pandemi Tarihinde Üç Hastalık ve Covid-19 Pandemisinin Sosyal Etkisinin $\mathrm{Bu}$ Hastalıklarla Değerlendirilmesi. Journal of Turkish Studies, Volume 15(Volume $15 \quad$ Issue 4), 1215-1226. https://doi.org/10.7827/turkishstudies.44303

Wikipedia Web Page. (2020). Retrieved March 10, 2021, from https://tr.wikipedia.org/wiki/Pandemik_İnfluenza_Ulusal_ Hazırlık_Planı

Worldometers. (n.d.). Retrieved May 29, 2021, from https://www.worldometers.info/coronavirus/ 